\title{
MARINE CARBON RESERVOIR AGE ESTIMATES FOR THE FAR SOUTH COAST OF PERU
}

\author{
Bruce D Owen \\ Department of Anthropology and Linguistics, Sonoma State University, Rohnert Park, California 94928, USA. \\ Email: OwenBruce@aol.com
}

\begin{abstract}
In order to estimate the apparent age of seawater $(\mathrm{R})$ and the corresponding local offset from the global marine radiocarbon calibration curve $(\Delta \mathrm{R})$ on the far south coast of Peru for 2 periods in the past, 6 pairs of associated marine shell and unburned wood samples from archaeological excavations at Loreto Viejo were ${ }^{14} \mathrm{C}$ dated. Three pairs from about cal AD 1280-1380 indicated larger and more variable $\Delta \mathrm{R}$ estimates than have been obtained for other periods in nearby regions, suggesting that $\Delta \mathrm{R}$ may vary considerably over space and/or time. Three pairs from about 1870-1680 cal BC yielded consistent shell dates, but only one reasonable terrestrial date and $\Delta \mathrm{R}$ estimate, probably due to stratigraphic mixing in antiquity. The one early $\Delta \mathrm{R}$ estimate falls slightly outside the range of the later ones, suggesting either still greater spatial variability in $\Delta \mathrm{R}$, or some temporal variability.
\end{abstract}

\section{INTRODUCTION}

In order to calibrate radiocarbon ages from archaeological marine shell excavated near Ilo, Peru $\left(17^{\circ} 37^{\prime} \mathrm{S}, 71^{\circ} 20^{\prime} \mathrm{W}\right)$ (Figure 1), and to estimate how much a partially marine diet could have perturbed the apparent ${ }^{14} \mathrm{C}$ ages of human bones and tissue from this area, it is necessary to know the apparent age of local sea water $(\mathrm{R})$ and the corresponding local offset from the global marine carbon calibration curve $(\Delta \mathrm{R})$ at the time of interest (Beavan and Sparks 1998; Beavan-Athfield 2001; Ingram 1998; Kennett et al. 1997, 2002; Molto et al. 1997; Stuiver et al. 1986; Stuiver and Braziunas 1993; Tauber 1983). Taylor and Berger (1967) assayed 4 shells collected at known times in the early 20th century on the coast of Peru and northern Chile, from about $10^{\circ} \mathrm{S}$ to about $33^{\circ} \mathrm{S}$. The local reservoir ages indicated by 3 of these shells were in rough agreement, yielding $\Delta \mathrm{R}$ estimates from $171 \pm 34$ to $307 \pm 77$. The shell from closest to Ilo (a gastropod collected around $15^{\circ} \mathrm{S}$ ) indicated a much greater reservoir age $(\Delta \mathrm{R}=664 \pm 45)$. This value, while not unprecedented, is very high and was excluded by Stuiver et al. (1986: Table 1) from their survey of regional $\Delta \mathrm{R}$ estimates. The shell may have provided a false estimate because it was old when collected or was affected by geological carbonate (Dye 1994), or it may reflect a correct localized extreme value due to fluvial water depletion (Little 1993) or other factors.

Southon et al. (1995) estimated $\Delta \mathrm{R}$ for a region south of Ilo (around $20^{\circ} \mathrm{S}$ ) during roughly cal AD 200-900, reporting 4 tightly clustered values that were close to Stuiver et al.'s (1986) regional mean. This finding suggested that the regional value was correct, and that it was relatively constant during the last two millennia. Estimates by Southon et al. (1995) were based on composite archaeological artifacts made from marine bird tissues and terrestrial plant fibers, ensuring excellent contemporaneity of the samples. Because marine birds are mobile, their tissues may average out small-scale spatial variations in the marine carbon reservoir. This could contribute to the good agreement among the estimates, but might mask localized extremes.

Kennett et al. (2002) tried to estimate $\Delta \mathrm{R}$ for the Ilo region during the Late Archaic Period (about $6000-4000$ cal BC) using associated shell and charcoal samples from the site of Kilometer 4, but were thwarted because the ancient inhabitants apparently collected very old wood for fuel.

\section{MATERIALS AND METHODS}

Six pairs of marine shell and terrestrial plant samples were ${ }^{14} \mathrm{C}$ dated. Each pair was from a single archaeological stratum at the site of Loreto Viejo $\left(17^{\circ} 36^{\prime} 8^{\prime \prime} \mathrm{S}, 71^{\circ} 13^{\prime} 45^{\prime \prime} \mathrm{W}\right)$ in the coastal Osmore 
valley, about $13 \mathrm{~km}$ inland from Ilo (Owen 1993). The samples were collected from 1/4 inch screens in the course of stratigraphic excavations. Extreme aridity and salty soil contribute to extraordinary preservation of plentiful desiccated plant material. Three sample pairs were from domestic middens that contained Chiribaya style ceramics and dated to cal AD 1280-1380 (1 $\sigma$; Table 1). The other 3 pairs were from a cooking area in a preceramic and early ceramic sector of the site, dating to 1870$1680 \mathrm{cal} \mathrm{BC}(1 \sigma$; Table 1$)$. Strata selected for sampling were well-defined by changes in soil texture and color, in order to reduce the chance of conflating samples from different depositional events. The selected strata were of low volume (Table 1), in order to ensure that each pair of samples was probably deposited within a relatively short period.
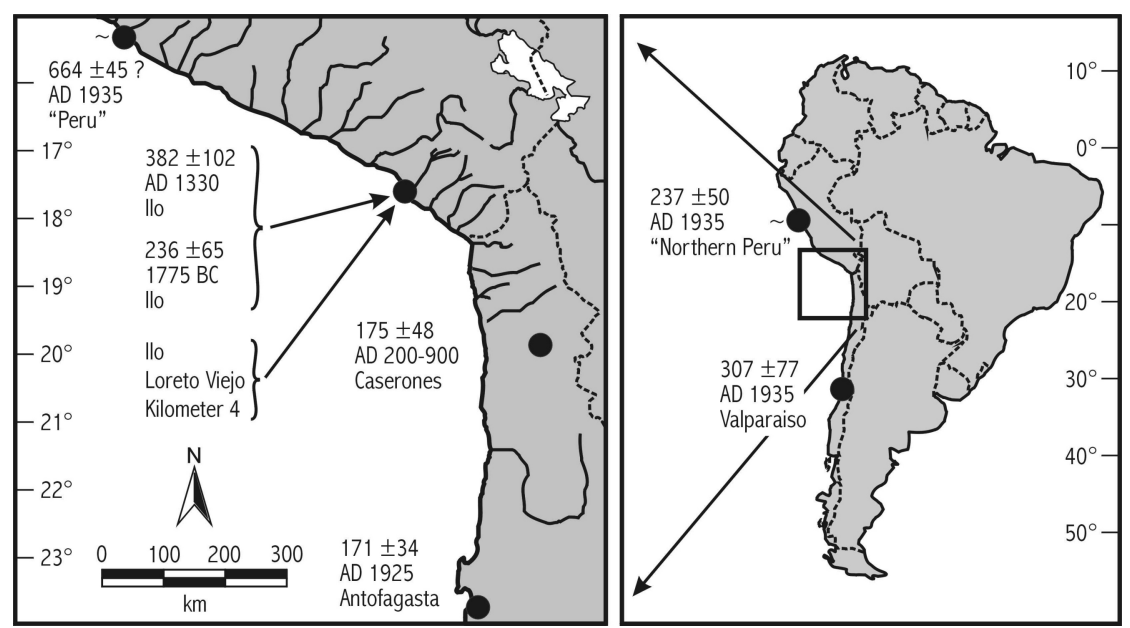

Figure $1 \Delta \mathrm{R}$ estimates for the Andean coast at various periods (with 40-yr Southern Hemisphere correction)

\section{SAMPLES}

Five of the 6 terrestrial samples were small unburned twigs of Schinus molle (California pepper tree, or molle) with bark. The remaining sample included twigs of both molle and unidentified species. The twigs ranged from 1 to $3 \mathrm{~mm}$ in diameter, which should ensure that they contain atmospheric carbon fixed during a period of no more than 2 or 3 yr. Such small twigs are unlikely to be "old wood" that was curated or collected from long-dead sources.

The marine samples were all fragments of Choromytilus chorus (choro mussel, or purple mussel) shell. Subtidal shellfish are preferable for marine carbon reservoir studies, because they are not exposed to atmospheric carbon during life (Goodfriend and Rollins 1998). Sandweiss et al. (1989) classify archaeological $C$. chorus from the nearby Ring Site as subtidal, and other sources treat $C$. chorus as primarily or entirely subtidal (Hancock 1969; Jaramillo et al. 1992; Soot-Ryen 1955). Intertidal Choromytilus are reported, but they are scarce, small, and of poor quality (Hancock 1969; Lasiak 1991). The archaeological specimens tend to be gigantic by modern standards, and they are ubiquitous in archaeological deposits, suggesting subtidal sources. If any of the samples were intertidal, $\Delta \mathrm{R}$ estimates from them would be incorrectly low. Some grazing gastropods metabolize old carbon from seafloor minerals, exaggerating $\Delta \mathrm{R}$ estimates based on their shells (Dye 1994; Phelan 1999). As a sessile bivalve, C. chorus should be less subject to this source of error. Since C. chorus shells in this region were rarely, if ever, worked, the mussels were probably collected live for food, making them contemporary with young twigs in the same contexts. 
Table 1 Marine-terrestrial date pairs from Loreto Viejo (see notes on page 705)

\begin{tabular}{|c|c|c|c|c|c|c|c|c|c|c|c|}
\hline Sample pair & Sample ID & Material and context & $\begin{array}{l}\delta^{13} \mathrm{C} \\
(\% 0)\end{array}$ & ${ }^{14} \mathrm{C}_{\mathrm{age}} \mathrm{a}^{\mathrm{a}}$ & $\begin{array}{l}\text { Apparent } \\
\text { age of } \\
\text { seawater }\end{array}$ & $\begin{array}{l}\text { Cal AD } \\
\pm 1 \sigma^{\circ} \\
\text { No } \mathrm{SHC}^{e} \\
\end{array}$ & $\begin{array}{l}\text { Model } \\
\text { marine age } \\
\text { No SHC }^{\mathrm{d}} \\
\end{array}$ & $\begin{array}{l}\Delta R^{f} \\
\text { No } S_{H C}\end{array}$ & $\begin{array}{l}\text { Cal AD } \\
\pm 1 \sigma^{\circ} \\
\text { With SHC } \\
\end{array}$ & $\begin{array}{l}\text { Model } \\
\text { marine age } \\
\text { With SHC }^{\mathrm{d}} \\
\end{array}$ & $\begin{array}{l}\Delta \mathrm{R}^{\mathrm{f}} \\
\text { With } \mathrm{SHC}^{\mathrm{g}} \\
\end{array}$ \\
\hline \multicolumn{12}{|c|}{ Chiribaya midden, cal AD 1280-1380 (1 $\sigma)$} \\
\hline \multirow{2}{*}{$\begin{array}{l}\text { Unit } 2505-5-6 \\
\text { midden, near top } \\
\text { (279 liters) }\end{array}$} & Beta 51073 & $\begin{array}{l}\text { Small twigs of Schinus } \\
\text { molle and other species }\end{array}$ & -26.3 & $730 \pm 60$ & & $1220-1390$ & & & $1270-1390$ & & \\
\hline & AA37160 & $\begin{array}{l}\text { Choromytilus chorus } \\
\text { shell }\end{array}$ & 0.3 & $1358 \pm 46$ & $628 \pm 76$ & $640-770$ & $1100 \pm 85$ & $258 \pm 97$ & $660-770$ & $1070 \pm 70$ & $288 \pm 84$ \\
\hline \multirow{2}{*}{$\begin{array}{l}\text { Unit } 2505-11-17 \\
\text { midden, near } \\
\text { bottom } \\
\text { ( } 48 \text { liters) }\end{array}$} & AA37161 & $\begin{array}{l}\text { Small twigs of Schinus } \\
\text { molle }\end{array}$ & -27.7 & $701 \pm 38$ & & $1270-1390$ & & & $1285-1390$ & & \\
\hline & AA37162 & $\begin{array}{l}\text { Choromytilus chorus } \\
\text { shell }\end{array}$ & 0.4 & $1428 \pm 56$ & $727 \pm 68$ & $560-665$ & $1070 \pm 70$ & $358 \pm 90$ & $600-690$ & $1060 \pm 60$ & $368 \pm 82$ \\
\hline \multirow{2}{*}{$\begin{array}{l}\text { Unit } 2503-6-6 \\
\text { midden } \\
\text { (44 liters) }\end{array}$} & AA40291 & $\begin{array}{l}\text { Small twigs of Schinus } \\
\text { molle }\end{array}$ & -26.3 & $662 \pm 34$ & & $1285-1390$ & & & $1300-1395$ & & \\
\hline & AA40292 & $\begin{array}{l}\text { Choromytilus chorus } \\
\text { shell }\end{array}$ & 0.0 & $1530 \pm 40$ & $868 \pm 52$ & $430-600$ & $1060 \pm 60$ & $470 \pm 72$ & $535-620$ & $1040 \pm 60$ & $490 \pm 72$ \\
\hline \multicolumn{2}{|l|}{$\begin{array}{l}\text { Weighted means } \\
\text { Means w/ std dev }\end{array}$} & & & & $\begin{array}{l}772 \pm 36 \\
741 \pm 121\end{array}$ & & & $\begin{array}{l}384 \pm 49 \\
362 \pm 106\end{array}$ & & & $\begin{array}{l}393 \pm 45 \\
382 \pm 102\end{array}$ \\
\hline \multicolumn{12}{|c|}{ Early cooking area, $1870-1680 \mathrm{cal} \mathrm{BC}(1 \sigma)$} \\
\hline \multirow{2}{*}{$\begin{array}{l}\text { Unit } 2513-5-4 \\
\text { around hearth, near } \\
\text { top } \\
\text { (36 liters) }\end{array}$} & $\mathrm{AA} 37163^{\mathrm{j}}$ & $\begin{array}{l}\text { Small twigs of Schinus } \\
\text { molle }\end{array}$ & -27.3 & $1895 \pm 28^{j}$ & & $65-135$ & & & $125-220$ & & \\
\hline & AA37164 & $\begin{array}{l}\text { Choromytilus chorus } \\
\text { shell }\end{array}$ & -0.8 & $3936 \pm 55$ & $2041 \pm 62^{k}$ & $\begin{array}{l}-2560- \\
-2310\end{array}$ & $2250 \pm 30$ & $1686 \pm 63^{k}$ & $\begin{array}{l}-2470- \\
-2300\end{array}$ & $2190 \pm 35$ & $1746 \pm 65^{k}$ \\
\hline \multirow{2}{*}{$\begin{array}{l}\text { Unit 2513-14-33 } \\
\text { pit fill, middle } \\
\text { (9 liters) }\end{array}$} & AA40293 & $\begin{array}{l}\text { Small twigs of Schinus } \\
\text { molle }\end{array}$ & -25.7 & $1519 \pm 31^{1}$ & & $440-610$ & & & $540-620$ & & \\
\hline & AA40294 & $\begin{array}{l}\text { Choromytilus chorus } \\
\text { shell }\end{array}$ & -0.1 & $3951 \pm 46$ & $2432 \pm 55^{k}$ & $\begin{array}{l}-2560- \\
-2340\end{array}$ & $1885 \pm 75$ & $2066 \pm 88^{k}$ & $\begin{array}{l}-2470- \\
-2310\end{array}$ & $1840 \pm 33$ & $2111 \pm 57^{k}$ \\
\hline \multirow{2}{*}{$\begin{array}{l}\text { Unit } 2513-11-18 \\
\text { ashy surface, near } \\
\text { bottom } \\
\text { ( } 75 \text { liters) }\end{array}$} & AA37165 & $\begin{array}{l}\text { Small twigs of Schinus } \\
\text { molle }\end{array}$ & -26.7 & $3439 \pm 43$ & & $\begin{array}{l}-1870- \\
-1680\end{array}$ & & & $\begin{array}{l}-1750- \\
-1620\end{array}$ & & \\
\hline & AA37166 & $\begin{array}{l}\text { Choromytilus chorus } \\
\text { shell }\end{array}$ & -0.1 & $3961 \pm 47$ & $522 \pm 64$ & $\begin{array}{l}-2570- \\
-2350 \\
\end{array}$ & $3790 \pm 70$ & $171 \pm 84$ & $\begin{array}{l}-2470- \\
-2310 \\
\end{array}$ & $3725 \pm 45$ & $236 \pm 65$ \\
\hline
\end{tabular}


Table 2 Marine-terrestrial date pairs from neighboring regions (see notes on page 705)

\begin{tabular}{|c|c|c|c|c|c|c|c|c|c|c|c|}
\hline Sample pair & Sample ID & Material and context & $\begin{array}{l}\delta^{13} \mathrm{C} \\
(\% 0)\end{array}$ & ${ }^{14} \mathrm{C}$ age ${ }^{\mathrm{a}}$ & $\begin{array}{l}\text { Apparent } \\
\text { age of } \\
\text { seawater }\end{array}$ & $\begin{array}{l}\text { Cal AD } \\
\pm 1 \sigma^{\circ} \\
\text { No } \mathrm{SHC}^{e} \\
\end{array}$ & $\begin{array}{l}\text { Model } \\
\text { marine age } \\
\text { No SHC }^{\mathrm{d}} \\
\end{array}$ & $\begin{array}{l}\Delta R^{\mathrm{f}} \\
\text { No } S H C^{e}\end{array}$ & $\begin{array}{l}\text { Cal AD } \\
\pm 1 \sigma^{\circ} \\
\text { With SHC } \\
\end{array}$ & $\begin{array}{l}\text { Model } \\
\text { marine age } \\
\text { With SHC }^{\mathrm{d}} \\
\end{array}$ & $\begin{array}{l}\mathrm{R}^{\mathrm{I}} \\
\text { With } \\
\mathrm{SHC}^{\mathrm{g}} \\
\end{array}$ \\
\hline \multicolumn{12}{|c|}{ Composite artifacts from Caserones, northern Chile, cal AD 200-900 (Southon et al. } \\
\hline \multirow[t]{2}{*}{ CAS572 } & CAMS 10320 & Plant fiber & -23.5 & $1270 \pm 60$ & & $660-860$ & & & $690-890$ & & \\
\hline & $\begin{array}{l}\text { CAMS } 10321 \\
\text { and } 10322\end{array}$ & $\begin{array}{l}\text { Fish vertebra and skin } \\
\text { or stomach (mean) }\end{array}$ & $\begin{array}{l}-12.8 \\
-14.5\end{array}$ & $1770 \pm 35$ & $500 \pm 69$ & $220-340$ & $1640 \pm 95$ & $130 \pm 101$ & $250-390$ & $1610 \pm 95$ & $160 \pm 95$ \\
\hline \multirow[t]{2}{*}{ CAS512 } & $\begin{array}{l}\text { CAMS } 9372 \\
\text { and } 9373\end{array}$ & $\begin{array}{l}\text { Wool yam (mean of } \\
\text { two samples) }\end{array}$ & $\begin{array}{l}-20 \\
\text { (est.) }\end{array}$ & $1580 \pm 40$ & & $430-540$ & & & $430-600$ & & \\
\hline & $\begin{array}{l}\text { CAMS } 7610 \\
\text { and } 9374\end{array}$ & $\begin{array}{l}\text { Bird-skin cape (mean } \\
\text { of two samples) }\end{array}$ & -13.4 & $2060 \pm 40$ & $480 \pm 57$ & $-160-1$ & $1925 \pm 45$ & $135 \pm 60$ & $-90-60$ & $1895 \pm 75$ & $160 \pm 80$ \\
\hline \multirow[t]{2}{*}{ CASTr6/7 } & CAMS 10314 & Wool yarn & -20.2 & $1690 \pm 60$ & & $250-430$ & & & $260-530$ & & \\
\hline & $\begin{array}{l}\text { CAMS } 10315 \\
\text { and } 10316\end{array}$ & $\begin{array}{l}\text { Feather and bird skin } \\
\text { (mean of two samples) }\end{array}$ & $\begin{array}{l}-11.5 \\
-12.2\end{array}$ & $2225 \pm 50$ & $535 \pm 78$ & $-380-200$ & $2045 \pm 75$ & $180 \pm 90$ & $-360-170$ & $2000 \pm 110$ & $245 \pm 85$ \\
\hline \multirow[t]{2}{*}{ CAS93.031 } & CAMS 10317 & Wool yarn & -20.4 & $1850 \pm 70$ & & $80-250$ & & & $120-330$ & & \\
\hline & $\begin{array}{l}\text { CAMS } 10318 \\
\text { and } 10319\end{array}$ & $\begin{array}{l}\text { Bird-skin cape (mean } \\
\text { of two samples) }\end{array}$ & $\begin{array}{l}-13.1 \\
-13.6\end{array}$ & $2295 \pm 50$ & $445 \pm 86$ & $-410-210$ & $2195 \pm 70$ & $100 \pm 86$ & $-400-200$ & $2145 \pm 85$ & $135 \pm 110$ \\
\hline $\begin{array}{l}\text { Weighted means }{ }^{\mathrm{h}} \\
\text { Means w/ std dev }{ }^{\mathrm{i}}\end{array}$ & & & & & $\begin{array}{l}490 \pm 35 \\
490 \pm 38\end{array}$ & & & $\begin{array}{l}136 \pm 40 \\
136 \pm 33\end{array}$ & & & $\begin{array}{l}180 \pm 45 \\
175 \pm 48\end{array}$ \\
\hline \multicolumn{12}{|c|}{ Historical shells, early $20^{\text {th }}$ century (Taylor and Berger 1967 ; Stuiver et al. 1986, table 1) } \\
\hline "Northern Peru" & UCLA 1282 & $\begin{array}{l}\text { Strombus peruvianus } \\
\text { shell collected } 1930- \\
1940\end{array}$ & -0.2 & $700 \pm 49$ & $685 \pm 49$ & & $463 \pm 10$ & $237 \pm 50$ & & & \\
\hline "Penu" & UCLA 1279 & $\begin{array}{l}\text { Oliva perwiana shell } \\
\text { collected } 1930-1940\end{array}$ & 1.2 & $1127 \pm 44$ & $1112 \pm 44^{k}$ & & $463 \pm 10$ & $664 \pm 45^{k}$ & & & \\
\hline $\begin{array}{l}\text { "Antofagasta, } \\
\text { Chile" }\end{array}$ & UCLA 1277 & $\begin{array}{l}\text { Concholepas } \\
\text { concholepas shell } \\
\text { collected } 1925\end{array}$ & 0.1 & $626 \pm 34$ & $601 \pm 34$ & & $455 \pm 4$ & $171 \pm 34$ & & & \\
\hline $\begin{array}{l}\text { "Valparaiso, } \\
\text { Chile" }\end{array}$ & UCLA 1278 & $\begin{array}{l}\text { Tegula aler shell } \\
\text { collected 1930-1940 }\end{array}$ & 1.3 & $770 \pm 76$ & $755 \pm 76$ & & $463 \pm 10$ & $307 \pm 77$ & & & \\
\hline $\begin{array}{l}\text { Weighted means }{ }^{\mathrm{h}} \\
\text { excluding } 1279\end{array}$ & & & & & $643 \pm 26$ & & & $206 \pm 27$ & & & \\
\hline $\begin{array}{l}\text { Means w/ std dev } \\
\text { excluding } 1279\end{array}$ & & & & & $680 \pm 21$ & & & $238 \pm 21$ & & & \\
\hline
\end{tabular}


Table notes:

${ }^{a}$ Conventional radiocarbon age BP, including $\delta^{13} \mathrm{C}$ adjustment, no Southern Hemisphere correction.

${ }^{\mathrm{b}} \mathrm{Apparent}$ age of seawater is the difference between the conventional ${ }^{14} \mathrm{C}$ ages of the marine and terrestrial samples (Stuiver and Braziunas 1993:137). The error estimate is $\left(\sigma_{\text {marine }}{ }^{2}+\sigma_{\text {terrestrial }}{ }^{2}\right)^{1 / 2}$. This value is in ${ }^{14} \mathrm{C} \mathrm{yr}$ and is independent of the Southern Hemisphere correction.

${ }^{\mathrm{c} C}$ alibrated $\pm 1 \sigma$ date range calculated by OxCal v3.5 (Ramsey 2000), atmospheric calibration data from Stuiver et al. (1998).

dThe model marine age is the hypothetical age and error estimate that, when calibrated using OxCal v.3.5, the marine calibration curve (Stuiver et al 1998), and $\Delta \mathrm{R}=0$, produces the associated terrestrial calibrated $1 \sigma$ date range.

e"No SHC" indicates that no Southern Hemisphere correction has been included in the calculation.

${ }^{\mathrm{f}} \Delta \mathrm{R}$ is the difference between the measured marine ${ }^{14} \mathrm{C}$ age and the model marine age. The $\pm 1 \sigma$ error estimate is $\left(\sigma_{\text {measured }}^{2}+\sigma_{\text {model }}\right)^{1 / 2}$.

g“"With SHC" indicates that the Southern Hemisphere correction suggested by Stuiver and Braziunas (1993) has been included in the calculation by subtracting $40 \mathrm{yr}$ from the conventional ${ }^{14} \mathrm{C}$ age of the terrestrial sample prior to calibration and determination of the model marine age.

hWeighted means and error estimates after Bowman (1990:59).

${ }^{\mathrm{i}}$ Arithmetic mean and standard deviation of values.

jWeighted mean of one measurement on each of 2 graphite targets prepared from the same sample (Bowman 1990:59).

kUnreasonably large, presumably erroneous value.

'Weighted mean of 2 measurements on 1 graphite target and 1 measurement on a second target prepared from the same sample (Bowman 1990:59).

Eleven of the 12 samples were pretreated and assayed at the NSF-University of Arizona AMS Facility under the direction of George Burr. The remaining sample was measured conventionally by Beta Analytic. The wood samples were given AAA pretreatment. The shell samples were pretreated with an $\mathrm{HCl}$ bath to remove surface layers that could contain recrystalized calcium carbonate.

\section{ANALYTICAL METHODS}

$\Delta \mathrm{R}$ is calculated here as outlined by Stuiver et al. (1986) and Stuiver and Braziunas (1993), except that instead of a graphical intercept method (Southon et al. 1995; Facorellis and Maniatis 1998), a probability distribution method is adopted, using OxCal v3.5 (Ramsey 2000) with atmospheric and marine calibration data from Stuiver et al. (1998). The model marine age and error estimate are determined by successive approximations as the values that, when calibrated with the marine calibration curve, produce the same 1- $\sigma$ date range as the terrestrial sample produces when calibrated using the atmospheric calibration curve. The smooth shape of the marine calibration curve ensures that there is almost always a unique solution.

Stuiver and Braziunas (1993) recommend subtracting a 40-yr Southern Hemisphere correction (SHC) from the terrestrial date before calibration. Marine dates calibrated with the resulting $\Delta \mathrm{R}$ are comparable to terrestrial dates that incorporate the 40-yr SHC. However, few Andean archaeologists apply the SHC. Using a $\triangle \mathrm{R}$ that includes the SHC would produce calibrated marine dates that are biased $40{ }^{14} \mathrm{C}$ yr younger than terrestrial dates calibrated without the SHC. On the other hand, most $\Delta \mathrm{R}$ estimates are based on historically dated marine shells, the age of which is independent of any SHC. Marine dates calibrated with $\Delta \mathrm{R}$ estimates from historical shells are comparable to calibrated terrestrial dates only if the terrestrial dates are correctly adjusted for hemispheric and other reservoir offsets-whatever those actually are. Moreover, the appropriate value for the SHC is still under discussion (Stuiver and Braziunas 1998; McCormac et al 1998). Given these uncertainties, $\Delta \mathrm{R}$ is calculated here both with and without a 40-yr SHC. 
Multiple values are summarized as weighted means of the values and error estimates (Bowman 1990:59) and as simple means and standard deviations of the values. Following Stuiver et al. (1986: 982), the method that results in the larger error estimate in any given case is adopted.

\section{RESULTS AND DISCUSSION}

The results of the 6 date pairs are given in Table 1. Data from Southon et al. (1995), Taylor and Berger (1967), and Stuiver et al. (1986) are recalculated in the same manner in Table 2. The recalculated values differ only slightly from the originally published results.

The weighted mean terrestrial conventional age for the 3 Chiribaya contexts is $687 \pm 23 \mathrm{BP}$, or cal AD 1280-1380 $(1 \sigma)$ without SHC. This range is as expected for the Chiribaya ceramic style. The 3 $\Delta \mathrm{R}$ estimates are of credible magnitudes and are roughly consistent, averaging $363 \pm 106$ without SHC or $382 \pm 102$ with SHC. These estimates are considerably higher and more variable than those from previous studies (Table 2).

The tight clustering of the terrestrial dates suggests that the archaeological deposits accumulated over a brief period, so the variability is probably not due to poor contemporaneity of the paired samples, nor to temporal variations in $\Delta R$. If the variation reflects spatial clines in $\Delta R$, these must occur over very small distances, since all the shell probably came from within walking distance of Loreto Viejo. Such small-scale variation might be caused by the contribution of fluvial water at the river's mouth (Little 1993).

Estimated $\Delta \mathrm{R}$ near Ilo about cal $\mathrm{AD} 1330$ is high compared to the general region in the early 20th century (Taylor and Berger 1967; Stuiver et al. 1986) and to northern Chile around cal AD 200-900 (Southon et al. 1995). This could indicate temporal or spatial variability in $\Delta \mathrm{R}$. Alternatively, some of the new or previous $\Delta \mathrm{R}$ estimates could be inaccurate.

The results from the 3 earlier date pairs were erratic. The 3 shell dates were very close, suggesting that they correctly date the deposits. The weighted mean of the conventional ${ }^{14} \mathrm{C}$ ages of the marine shell is $3951 \pm 28 \mathrm{BP}$, or $1860-1680$ cal BC $(1 \sigma)$ without SHC using the single $\Delta \mathrm{R}$ estimate discussed below. The 3 terrestrial dates were wildly variable. Two were over $2000 \mathrm{yr}$ younger than the shells, indicating such extreme reservoir ages that they must be in error. The third indicates a believable $\Delta \mathrm{R}$ estimate of $171 \pm 84$ without SHC or $236 \pm 65$ with SHC.

Both anomalous terrestrial dates were re-measured using new graphite targets prepared from remaining portions of the samples. One dated within $1 \sigma$ of the first target, and the other agreed within $2 \sigma$, but both still suggested unreasonable reservoir ages. The twigs had been inspected under $10 \times$ magnification, and no decay or mold were noted. The discrepancy is probably not due to diagenetic changes or contamination of twigs that were contemporary with the shells, because an unreasonably high percentage of the carbon in the samples would have to be recent or modern to shift the apparent ages this much. The samples are unlikely to include post-occupation twigs, because the excavated area is on a barren desert hillside, over $200 \mathrm{~m}$ from the nearest irrigable land capable of sustaining a tree and $40 \mathrm{~m}$ above it. This is not an "old wood" problem, because the wood appears too young. It is unlikely to be an "old shell" problem, not only because the shell would have been collected fresh for food, but also because old shells collected on three different occasions would be unlikely to have such close ${ }^{14} \mathrm{C}$ ages.

The tightly clustered shell dates and the shallow cultural layers suggest that the entire sequence of deposits accumulated in a brief period, so there is no obvious source for drastically younger archaeological material. However, the stratum (2513-11-18) with a twig that gave a reasonable date is 
stratigraphically the earliest and best isolated from later deposits (Figure 2). The other 2 strata could contain twigs from a much more recent occupation, mixed in antiquity with shells from the earlier deposits that were brought up by digging the pit of 2513-14-33. Unfortunately, the material culture of this period is too simple and conservative to indicate on stylistic grounds whether the strata differ so significantly in time. This explanation implies exceedingly bad luck in sample selection, but it is possible. If it is correct, the sample pairs from 2513-5-4 and 2513-14-33 are not contemporary and cannot be used to estimate $\Delta \mathrm{R}$. On the other hand, this explanation gives no reason to reject the pair from 2513-11-18, providing one usable estimate of $\Delta \mathrm{R}$ for the early period.

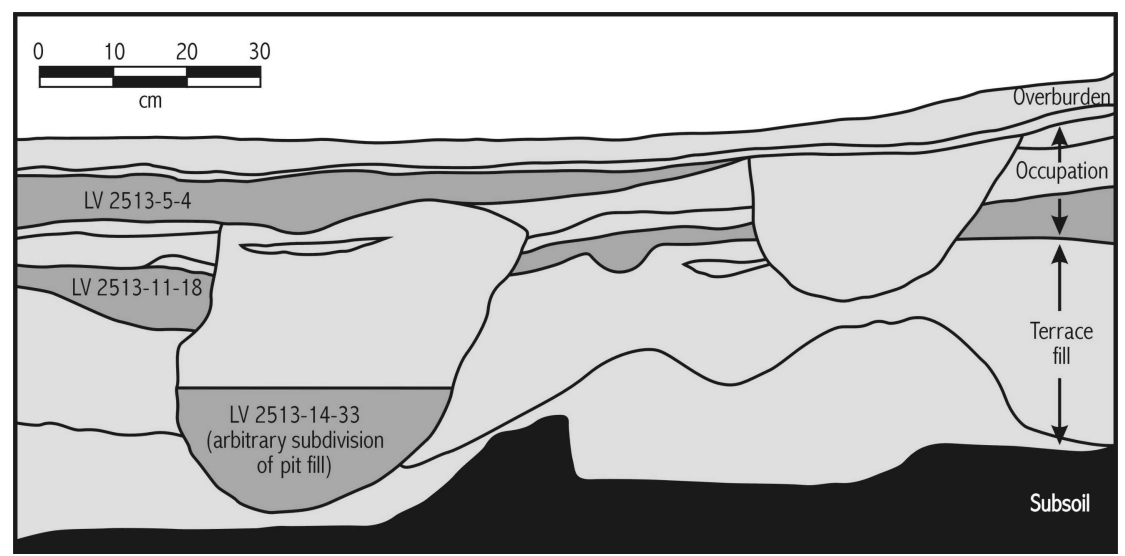

Figure 2 Strata sampled in the early cooking area at Loreto Viejo; north profile of unit LV 2513.

\section{CONCLUSIONS}

$\Delta \mathrm{R}$ near Ilo, Peru, around cal AD 1280-1380 (1 $\sigma)$ was about $362 \pm 106$ with no Southern Hemisphere correction, or $382 \pm 102$ with a 40 -yr Southern Hemisphere correction. These values are higher than previous estimates for nearby regions at different times (Taylor and Berger 1967; Stuiver et al. 1986; Southon et al. 1995). This disagreement suggests that estimates of $\Delta \mathrm{R}$ for this region should be used with caution, since there may be considerable spatial or temporal variation in marine ${ }^{14} \mathrm{C}$ reservoir depletion, or errors in some of the estimates.

One sample pair suggested a $\Delta \mathrm{R}$ estimate for around 1870-1680 cal BC $(1 \sigma)$ of about $171 \pm 84$ with no Southern Hemisphere correction, or $236 \pm 65$ with the 40-yr Southern Hemisphere correction. This estimate should be regarded as tentative, because 2 similar date pairs from nearby contexts gave erroneous results. While its lower magnitude is more in line with previously published estimates, it falls slightly outside the range of the other estimates reported here, accentuating the apparent variability of $\Delta \mathrm{R}$ over short distances and/or over time.

\section{ACKNOWLEDGMENTS}

The excavations at Loreto Viejo were authorized by the Peruvian government under Resolución Suprema No. 386-88-ED and funded by a Fulbright-Hays fellowship and National Science Foundation grant 8903227, with logistical support from the Southern Peru Copper Corporation through the Programa Contisuyo (now the Associación Contisuyo). Sample preparation and carbon isotope measurements of 11 of the 12 samples were funded by NSF grant 9982152, and were conducted by the NSF-University of Arizona AMS Facility under the direction of George Burr. The remaining sample was processed earlier by Beta Analytic under a grant from the Wenner-Gren Foundation. 
The Asociación Contisuyo assisted with travel costs. The Centro Mallqui, directed by Sonia Guillen, curated the archaeological material. Figure 2 and the associated discussion of stratigraphy are based on notes and drawings by José Moya Y and photos by the author. Doug Kennett provided useful comments and encouragement. John Southon's review stimulated a better analysis of the problematic early samples. Any errors are solely the responsibility of the author.

\section{REFERENCES}

Beavan NR, Sparks RJ. 1998. Factors influencing ${ }^{14} \mathrm{C}$ ages of the pacific rat Rattus exulans. Radiocarbon 40(2):601-13.

Beavan-Athfield NR, McFadgen BG, Sparks RJ. 2001. Environmental influences on dietary carbon and ${ }^{14} \mathrm{C}$ ages in modern rats and other species. Radiocarbon 43(1):7-14.

Bowman S. 1990. Radiocarbon dating. Berkeley: University of California Press.

Bronk Ramsey C. 2000. OxCal Program v3.5. University of Oxford Radiocarbon Accelerator Unit, Oxford.

Dye T. 1994. Apparent ages of marine shells: implications for archaeological dating in Hawai'i. Radiocarbon 36(1):51-7.

Facorellis Y, Maniatis Y. 1998. Apparent ${ }^{14} \mathrm{C}$ ages of marine mollusk shells from a Greek island: calculation of the marine reservoir effect in the Aegean Sea. Radiocarbon 40(2):963-73.

Goodfriend GA, Rollins HB. 1998. Recent barrier beach retreat in Georgia: dating exhumed salt marshes by aspartic acid racemization and post-bomb radiocarbon. Journal of Coastal Research 14(3):960-9.

Hancock DA. 1969. The shellfisheries of Chile. Publication No. 45. Santiago: Instituto de Fomento Pesquero.

Ingram B. 1998. Differences in radiocarbon age between shell and charcoal from a holocene shellmound in northern California. Quaternary Research 49:102-10.

Jaramillo E, Bertrán C, Bravo A. 1992. Community structure of the subtidal macroinfauna in an estuarine mussel bed in southern Chile. Marine Ecology 13(4): 317-31.

Kennett D, Ingram B, Erlandson J, Walker P. 1997. Evidence for temporal fluctuations in marine radiocarbon reservoir ages in the Santa Barbara Channel, southern California. Journal of Archaeological Science 24: 1051-9.

Kennett DJ, Ingram BL, Southon JR, Wise K. 2002. Differences in ${ }^{14} \mathrm{C}$ age between stratigraphically associated charcoal and marine shell from the archaic period site of Kilometer 4, southern Peru: Old wood or old water? Radiocarbon 44(1):53-8.

Lasiak T. 1991. Bucephalid trematode infections in mytilid bivalves from the rockery intertidal of southern Chile. Journal of Molluscan Studies 58(1): 199229-36.

Little EA. 1993. Radiocarbon age calibration at archaeological sites of coastal Massachusetts and vicinity. Journal of Archaeological Science 20:457-71.

McCormac FG, Hogg AG, Higham TFG, Baillie MGL,
Palmer JG, Xiong L, Pilcher JR, Brown D, Hoper ST. 1998. Variations of radiocarbon in tree rings: Southern Hemisphere offset preliminary results. Radiocarbon 40(3):1153-9.

Molto, JE, Stewart JD, Reimer PJ. 1997. Problems in radiocarbon dating human remains from arid coastal areas: an example from the Cape region of Baja California. American Antiquity 62(3):489-507.

Owen B. 1993. A model of multiethnicity: state collapse, competition, and social complexity from Tiwanaku to Chiribaya in the Osmore valley, Peru. PhD thesis. University of California, Los Angeles, USA.

Phelan M. 1999. A $\Delta$ R correction value for Samoa from known-age marine shells. Radiocarbon 41(1):99-101.

Sandweiss DH, Richardson JB, Reitz EJ, Hsu JT, Feldman RA. 1989. Early maritime adaptations in the Andes: preliminary studies at the Ring Site, Peru. In: Rice D, Stanish C, Scarr P, editors. Ecology, settlement and history in the Osmore Drainage, Peru. British Archaeological Reports International Series 545(i):35-84.

Soot-Ryen T. 1955. A report on the family Mytilidae (Pelecypoda). Allen Hancock Pacific Expeditions 20(1). Los Angeles: University of Southern California Press.

Southon JR, Rodman AO, True D. 1995. A comparison of marine and terrestrial radiocarbon ages from northern Chile. Radiocarbon 37(2):389-393.

Stuiver M, Braziunas TF. 1993. Modeling atmospheric ${ }^{14} \mathrm{C}$ influences and ${ }^{14} \mathrm{C}$ ages of marine samples to 10,000 BC. Radiocarbon 35(1):137-89.

Stuiver M, Braziunas TF. 1998. Anthropogenic and solar components of hemispheric ${ }^{14} \mathrm{C}$. Geophysical Research Letters 25:329-32.

Stuiver M, Pearson G, Braziunas TF. 1986. Radiocarbon age calibration of marine samples back to $9000 \mathrm{cal} \mathrm{yr}$ BP. Radiocarbon 28(2B):980-1021.

Stuiver M, Reimer PJ, Braziunas TF. 1998. High-precision radiocarbon age calibration for terrestrial and marine samples. Radiocarbon 40(3):1127-51.

Tauber, H. 1983. ${ }^{14} \mathrm{C}$ Dating of human beings in relation to dietary habits. In: Mook WK, Waterbolk HT, editors. PACT 8. Proceedings of the First International Symposium ${ }^{14}$ C and Archaeology. Strasbourg: Council of Europe. p 365-75.

Taylor R, Berger R. 1967. Radiocarbon content of marine shells from the pacific coasts of Central and South America. Science 158:1180-2. 